\title{
UDC 629.4.017:625.1.032.84
}

\section{A. O. SHVETS ${ }^{1 *}$, K. I. ZHELIEZNOV ${ }^{2 *}$,A. S. AKULOV ${ }^{3 *}$, O. M. ZABOLOTNYI ${ }^{4 *}$, YE. V. CHABANIUK ${ }^{*}$}

${ }^{1 *}$ EDSD MBCSS, Dnipropetrovsk National University of Railway Transport named after Academician V. Lazaryan, Lazaryan St., 2, Dnipropetrovsk, Ukraine, 49010, tel. +38 (050) 21414 19, e-mail angela_shvets@ua.fm, ORCID 0000-0002-8469-3902

${ }^{2 *}$ EDSD MBCSS, Dnipropetrovsk National University of Railway Transport named after Academician V. Lazaryan, Lazaryan St., 2, Dnipropetrovsk, Ukraine, 49010, tel. +38 (095) 54538 87, e-mail constantinz@i.ua, ORCID 0000-0003-3648-1769

$3^{3 *}$ EDSD MBCSS, Dnipropetrovsk National University of Railway Transport named after Academician V. Lazaryan, Lazaryan St., 2, Dnipropetrovsk, Ukraine, 49010, tel. +38 (067) 17816 90, e-mail asakulov@gmail.com, ORCID 0000-0002-6123-5431

${ }^{4 *}$ EDSD MBCSS, Dnipropetrovsk National University of Railway Transport named after Academician V. Lazaryan, Lazaryan St., 2, Dnipropetrovsk, Ukraine, 49010, tel. +38 (067) 28213 41, e-mail zabolotnyi@i.ua, ORCID 0000-0003-1651-7082

${ }^{5 *}$ EDSD MBCSS, Dnipropetrovsk National University of Railway Transport named after Academician V. Lazaryan, Lazaryan St., 2, Dnipropetrovsk, Ukraine, 49010, tel.+38 (066) 63355 95, e-mail 457m@ukr.net, ORCID 0000-0001-5695-5955

\section{DETERMINATION OF THE ISSUE CONCERNING THE LIFT RESISTANCE FACTOR OF LIGHTWEIGHT CAR}

Purpose. The analytical study of the connection between the longitudinal force, acting on the light-weight car, lateral and vertical forces of interaction in the contact zone «wheel - rail» with the lift resistance factor value is to provide a simple relationships between them. Methodology. Research was conducted by the method of mathematical modeling of loading the freight car when driving at different speeds on straight and curved sections of a track. Findings. Even in the absence of «lift» accordingly the classical train stability theory, as the hinge-rod system, the presence of the longitudinal compressive forces may become a factor provoking cars derailment. The main reason of wheel climbing on rails is the combination of processes of dynamic interaction between the hunting vehicle and the track with simultaneous action of longitudinal compressive forces, and not the destabilization of train as a hingedrod system. To assess the impact of the longitudinal forces value on the lift resistance factor there are presented the calculation results for the empty gondola car motion, model No. 12-532, on $250 \mathrm{~m}$ radius curve with $150 \mathrm{~mm}$ rise and cross starting of car underframe relating to the track axis in $50 \mathrm{~mm}$ guiding section. The calculations were made in such a curve excluding the inertial forces from outstanding acceleration and taking into account the unbalanced acceleration with the permissible speed of $65 \mathrm{~km} / \mathrm{h}$. Originality. This study provides the technique of determining the lift resistance factor by longitudinal forces, which is somewhat different from the standard one, as well as evaluates impact of rolling stock speed on this factor. Practical value. The authors clarify the current method of determining the lift resistance factor by longitudinal forces and assess the impact of rolling stock speed on the value of this factor. From these studies one can conclude that because of cars hunting their lift is possible even when the train as hinge-rod system does not lose stability. The developed proposals allow reducing the number of car derailment by taking into account important parameters and characteristics during the process of calculation and design that increase their stability in the rail track especially in case of increased speed of freight trains.

Keywords: traffic safety; rules for the calculation; car lift resistance factor; movement speed; lift resistance factor

\section{Introduction}

Traffic safety is a basic condition for normal operation of the railways. Problems of traffic safety of trains and shunting operations are the main ones for the rail transport since it is hard to completely avoid crashes and accidents occurring due to car derailment [9].
The main causes of accidents in locomotive economy of railways of Ukraine are a combination of car malfunctions and track condition, as well as foot-plate staff's actions leading to violations of train driving modes.

The traffic accident analysis of the locomotive facilities of Ukrainian railways for the period of 
$2008-2010$ (Fig. 1) shows that most of accidents are caused by the actions of foot-plate staff (Fig. 1a) and freight traffic - freight electric locomotives and diesel locomotives (Fig. $1 b$ ) $[1,16,20]$.

Since the driving of freight trains results in quite large longitudinal forces acting on cars, it becomes important to conduct the research aimed at identifying the causes of the situations in which the cars might be lifted.

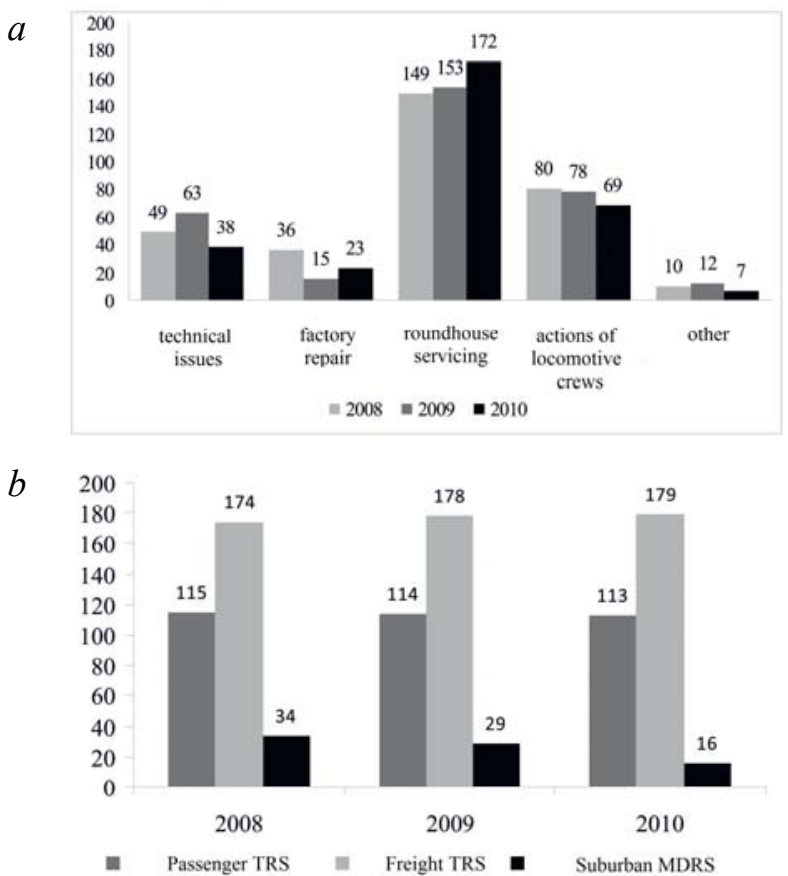

Fig. 1. The histogram of traffic accidents caused by locomotive facilities of Ukrainian railways: $a$-causes of transport accidents; $b$ - transport accidents by type of rolling stock and traction

Increased safety of freight car traffic is one of the priorities of the Ukrainian railways and it represents a set of measures aimed at reducing the likelihood of threat to life and health of passengers, transported goods, as well as at the safety of infrastructure and rolling stock of the railway transport, environmental safety.

For effective training of specialists in such a complex area as railway transport currently the simulator complexes are widely used [10]. The simulator is usually used for developing practical skills, bringing them to automatism, especially for modelling abnormal and emergency situations It is important for a simulator to have a high-quality mathematical model describing the longitudinal dynamic processes in train and able to assess the lift resistance of each car, since any discrepancy in the actual situation involves inadequate response of a locomotive driver when emergency situations occur in real life $[15,21]$.

\section{Purpose}

To ensure the stability the limit values for certain indicators are set. These indicators determine the conditions of rail top wheeling-in. One of such conditions is the ratio of lateral and vertical forces acting on the wheel. However, if the above indicators exceed the permissible limits, it does not mean that derailment will take place; it is the necessary but not sufficient condition for the wheel running off the rails [12].

When designing the new and upgrading the existing freight cars one of the mandatory conditions, which determines their suitability for use, is the fulfilment of conditions for ensuring the car resistance factor against the lift caused by longitudinal forces in the train.

The purpose of the analytical study of the relationship between the longitudinal force acting on the lightweight car, lateral and vertical forces acting in the contact area of the wheel flange and the rail with the lift resistance factor value is to provide simple functional connections between them.

\section{Methodology}

Wheel stability against re-railing is determined by two main factors: the ratio of the lateral interaction force to the vertical load on a wheel and by the angle of rail top side edge wheeling-in, which depend on dynamic processes of vehicle movement in the rail track and the longitudinal forces acting on the car in train.

As a result of the use of certain driving modes the train can evoke large longitudinal dynamic forces both tensile and compressive ones. The effect of the action of the longitudinal forces is defined by their direction and car position relative to the neighbouring vehicles in coupling $[2,3,7,8]$. When placing the cars at an angle to each other in the plan, the transverse horizontal components of the longitudinal forces appear; and in case of difference in height of their automatic couplings vertical components, which create additional loading or off-loading of the respective wheels of the 
vehicle $[3,6,13]$. This has an effect on the value of the lateral and vertical interaction forces, defining the conditions necessary for rail top wheeling-in $[23,24,25]$.

Since the set of the cars with central automatic couplings of shock-traction action is a multilink hinge-rod circuit, the instability of equilibrium of this mechanism depends on the location and characteristics of the horizontal and vertical components of the longitudinal forces [3]. The force, by analogy with Euler static problem, corresponding to hinge-rod circuit buckling moment, is called buckling (Fig. 2). The calculated buckling forces for freight cars occur the least ones when skewing according to the diagram (a). Consequently, the cars coaxially arranged on a straight track section would not be out of alignment under the action of compressive forces lower than the buckling one $[2,3]$. In fact, due to the meandering motion of vehicles, track gaps, spring, axle and centre plate arrangements, and for other reasons the cars almost always have some oblique settings relating to each other [2, 3, 6, 13].

Despite the fact that the theoretical studies found that, when the compressive force value is lower than the buckling value, the car lift should not occur due to the stability loss of the train as a hinged-rod system, the practice shows that the train derailments occur even at lower values of the longitudinal forces. This is particularly evident for the trains with empty cars, which are characterized by intense hunting in the operational speed range. Therefore, apart from the train longitudinal stability as a hinged-rod system, for the speeds above the critical speed of hunting, in the presence of the longitudinal compressive forces one must consider longitudinal and transverse stability of the motion of the train cars $[18,19]$.

It should be noted that the presence of longitudinal forces not only leads to an increased hunting, but also helps to reduce the vertical loads in the wheel-rail system, that is to reduce the forces that prevent rail top wheeling-in, as well as to a greater turn of carriages with increased angle of rail wheeling-in. In such situations, the rail top wheeling-in resistance is seen not as a direct result of the high value of the longitudinal force, but as a result of intense vibrations of the hunting vehicle. This is particularly evident in the area of transition curves, characterized by additional perturbations of impact nature $[2,3,6-8]$.

Let's consider the car motion in a curve, where there are different on both sides of the car cant angles of rigid rods (bodies) to the track plane $\varphi_{1}$ and $\varphi_{2}$, the angles of coupling rotation with respect to the track axis $\psi_{1}$ and $\psi_{2}$, and the car rotation within the gap in the track at an angle $\psi$. Herewith the car is set in the track under the diagram $(a)$ - «herringbone» and is subjected to the action of longitudinal compressive forces. We introduce a number of assumptions, simplifying the problem [6].

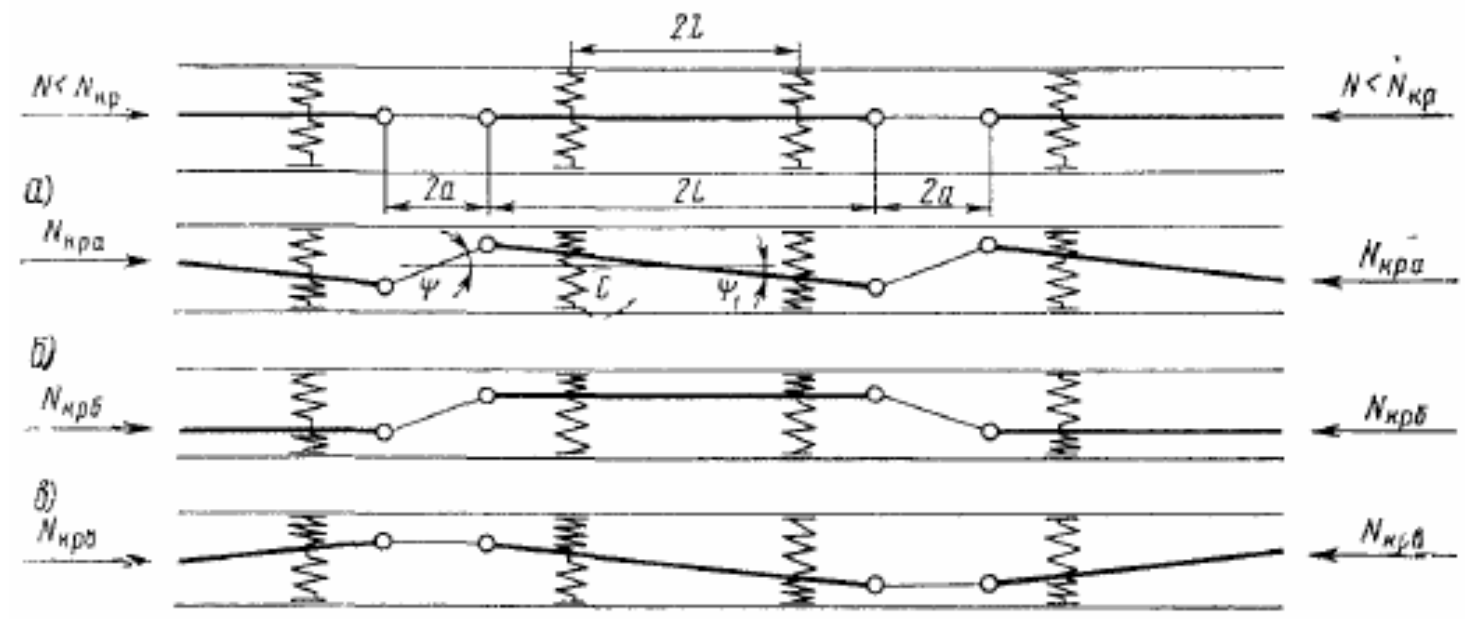

Fig. 2. Design diagram of the train and oblique settings of its elements in the plan under the action of longitudinal compressive forces 


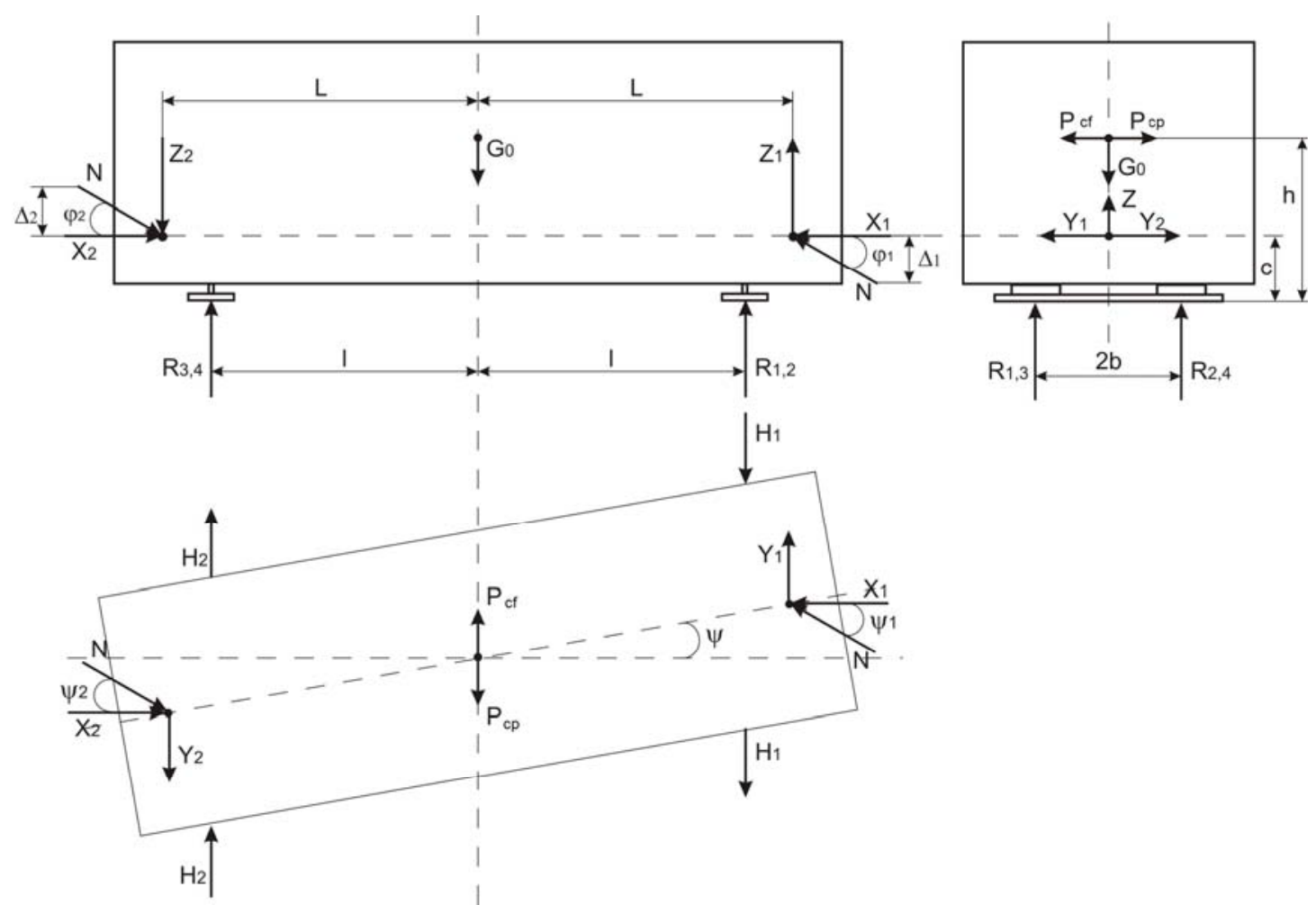

Fig. 3. The forces acting on the car

Fig. 3, all the forces acting on the car are designed on the track plane, as well as the planes perpendicular to it - the longitudinal, relative to the track, and the cross axis.

Where $G_{0}$-weight of the car body, $\mathrm{kN} ; P_{\mathrm{cf}}-$ centrifugal force, $\mathrm{kN}$;

$$
P_{c f}=\frac{G_{0} \cdot V^{2}}{g \cdot R},
$$

$P_{\mathrm{cp}}$-centripetal force, $\mathrm{kN}$;

$$
P_{c p}=G_{0} \cdot \alpha,
$$

$\alpha$ - track inclination angle towards the horizontal, rad; $N_{1}$ and $N_{2}$-longitudinal forces acting in a car coupler, $\mathrm{kN} ; Z_{1}$ and $Z_{2}$ - vertical components of the longitudinal force, $\mathrm{kN}$;

$$
\begin{aligned}
& Z_{1}=N \cdot \varphi_{1}, \quad \varphi_{1}=\frac{\Delta_{1}}{2 a} ; \\
& Z_{2}=N \cdot \varphi_{2}, \quad \varphi_{2}=\frac{\Delta_{2}}{2 a}
\end{aligned}
$$

$2 a$ - the distance between the centres of the cotter hole of automatic coupling, $\mathrm{m} ; \Delta_{1}-$ axe level difference of automatic couplings in front of the car, $\mathrm{m} ; \Delta_{2}-$ axe level difference of automatic couplings behind the car, $\mathrm{m}$;

$$
Y_{1}=N \cdot \psi_{1}, \quad Y_{2}=N \cdot \psi_{2}
$$

$Y_{1}$ and $Y_{2}$ - horizontal lateral components of the longitudinal force, $\mathrm{kN}$;

Since the angles $\varphi_{1}$ and $\varphi_{2}, \psi_{1}$ and $\psi_{2}$ are rather small, then:

$$
X_{1}=X_{2}=N .
$$

$X_{1}$ and $X_{2}$ - horizontal longitudinal components of the longitudinal force, $\mathrm{kN}$.

Assuming that the turning angles of all cars in a curve are equal, we find:

$$
\begin{gathered}
\psi=\frac{\delta_{0}}{2 \cdot \ell}, \\
\psi_{1}=\frac{\delta_{0} \cdot L}{2 a \cdot \ell}+\frac{L_{c}}{R}, \\
\psi_{2}=\frac{\delta_{0} \cdot L}{2 a \cdot \ell}-\frac{L_{c}}{R} ;
\end{gathered}
$$

In view of the elastic transverse deformation of the bogie spring sets the formulas $(7,8,9)$ take the following form: 


$$
\begin{aligned}
\begin{array}{l}
\psi= \\
2 \cdot \ell
\end{array} & \frac{\delta_{0}}{4 \ell \cdot C_{\Gamma}} \times \\
& \times\left[\frac{\delta_{0} \cdot L}{\ell^{2}} \cdot\left(1+\frac{L}{a}\right)+\frac{2 L_{c}}{R}\right], \\
\psi_{1}= & \frac{\delta_{0} \cdot L}{2 a \cdot \ell}+\frac{N}{4 C_{\Gamma}} \times \\
& \times\left[\frac{\delta_{0} \cdot L}{\ell^{2}} \cdot\left(1+\frac{L}{a}\right)+\frac{2 L_{c}}{R}\right] \cdot \frac{L}{a \ell}+\frac{L_{c}}{R}, \\
\psi_{2}= & \frac{\delta_{0} \cdot L}{2 a \cdot \ell}+\frac{N}{4 C_{\Gamma}} \times \\
& \times\left[\frac{\delta_{0} \cdot L}{\ell^{2}} \cdot\left(1+\frac{L}{a}\right)+\frac{2 L_{c}}{R}\right] \cdot \frac{L}{a \ell}-\frac{L_{c}}{R} ;
\end{aligned}
$$

where $2 L_{\mathrm{c}}$ - car coupled length, m; $2 \ell$ - truckcentre spacing, $\mathrm{m} ; R$ - curve radius, $\mathrm{m} ; 2 \delta_{0}-$ total cross-run play of the car body frame relative to the track axis in the run section, $\mathrm{m} ; L-$ horizontal distance from the car axis to the cotter hole centre of automatic coupling, $\mathrm{m} ; a$ - coupler casting length (from the axis of coupling to the end of the shank), $\mathrm{m} ; C_{\mathrm{h}}-$ horizontal stiffness of the spring suspension of a bogie, $\mathrm{kN} / \mathrm{m}$.

The vertical components of support reactions are indicated in Fig. 3 as R1, R2, R3, R4, the horizontal components of the reactions belonging to the same bogie are taken equal to each other (the assumption is made about the equality of the horizontal lateral stiffness of spring group on one bogie) and denoted $H_{1}$ and $H_{2}$.

Having formed the equations of equilibrium and compatibility of vertical displacements (vertical stiffness of all the spring sets are equal, and the car frame is absolutely rigid), we determine the reactions of the supports:

$$
\begin{gathered}
\varphi_{\ni}=\varphi_{1} \cdot\left(\frac{L}{\ell}+1\right)+\varphi_{2} \cdot\left(\frac{L}{\ell}-1\right), \\
R_{1}=\frac{G_{0}}{4}-\frac{N}{4} \cdot \varphi_{\ni}+\frac{N}{4} \times \\
\quad \times \frac{c}{b} \cdot\left(\psi_{1}-\psi_{2}\right)+\frac{G_{0}}{4} \cdot \frac{h}{g b} \cdot a_{u n}, \\
R_{2}=\frac{G_{0}}{4}-\frac{N}{4} \cdot \varphi_{\ni}-\frac{N}{4} \times \\
\quad \times \frac{c}{b} \cdot\left(\psi_{1}-\psi_{2}\right)-\frac{G_{0}}{4} \cdot \frac{h}{g b} \cdot a_{u n},
\end{gathered}
$$

$H_{1}=N / 4 \times$

$$
\begin{array}{r}
\times\left(\varphi_{1} \cdot\left(\frac{L}{\ell}+1\right)+\varphi_{2} \cdot\left(\frac{L}{\ell}-1\right)+2 \varphi \cdot \frac{L}{\ell}\right)+ \\
+\frac{G_{0}}{2 g} \cdot a_{u n} .
\end{array}
$$

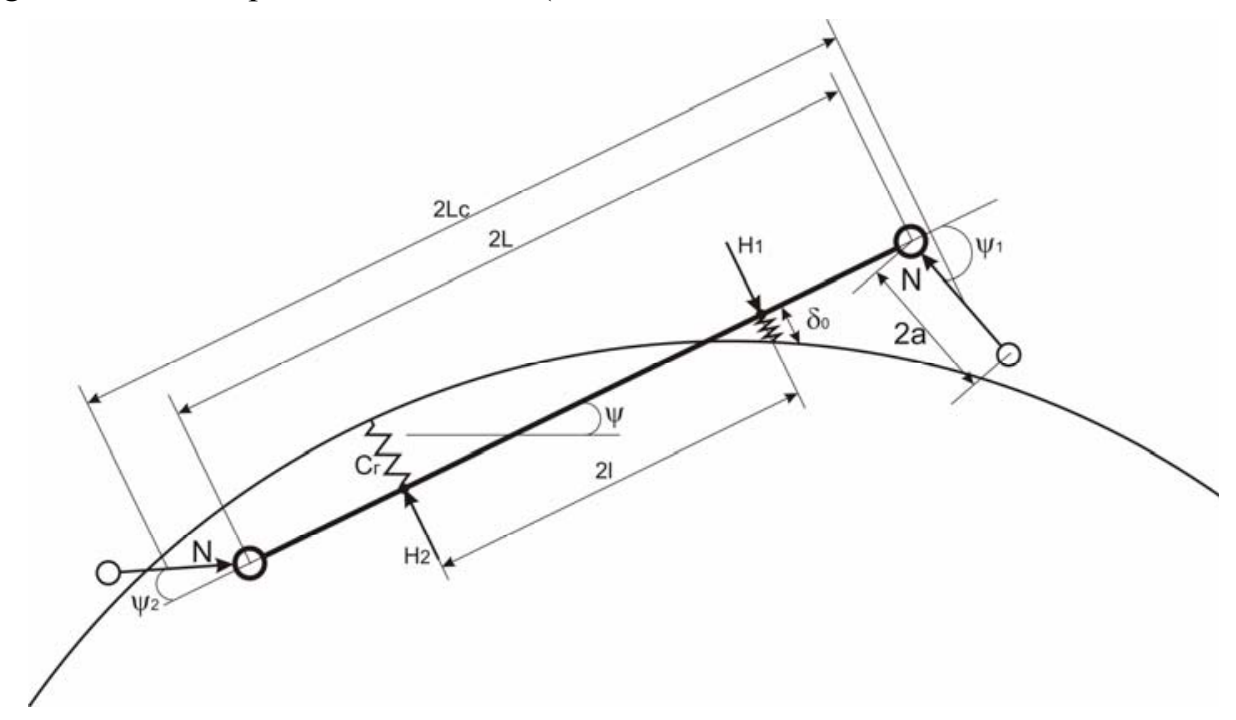

Fig. 4. Car layout on a curved track section under the action of longitudinal compressive forces 
Where $2 b$ - distance between the points of application of the vertical forces acting on the journal box of the wheel pair on the climbing and non-climbing wheel respectively, $\mathrm{kN}$; $h$ - height of the car body centre of gravity over the bolster supporting plane, $\mathrm{m} ; c$ - vertical distance from the top plane of the central spring set to the coupling axis level, m; $a_{\text {un }}$ - unbalanced acceleration, $\mathrm{m} / \mathrm{s}^{2} ; g$ - gravity acceleration, $\mathrm{m} / \mathrm{s}^{2}$.

Having considered the balance of non-sprig part of the bogie, we can find vertical $P_{1}, P_{2}$ and the horizontal force $H_{f}$ acting on the wheel pair:

$$
\begin{aligned}
& P_{1}=\frac{G_{1}}{4}+\frac{R_{1}}{2} \\
& P_{2}=\frac{G_{1}}{4}+\frac{R_{2}}{2} \\
& H_{f}=H_{1}+\frac{G_{1}}{2 g} \cdot a_{u n} \text {. } \\
& P_{c a r}=\frac{G_{0}}{8}+\frac{G_{b g}}{4}+\frac{N}{8} \cdot\left[\left(\psi_{1}-\psi_{2}\right) \cdot \frac{h_{a}}{S}-\left(\varphi_{1}-\varphi_{2}\right) \cdot \frac{L \cdot b}{\ell \cdot S}-\left(\varphi_{1}-\varphi_{2}\right) \cdot \frac{b}{S}+\left(\psi_{1}+\psi_{2}+2 \psi\right) \cdot \frac{L \cdot h_{h s}}{\ell \cdot S}\right],
\end{aligned}
$$

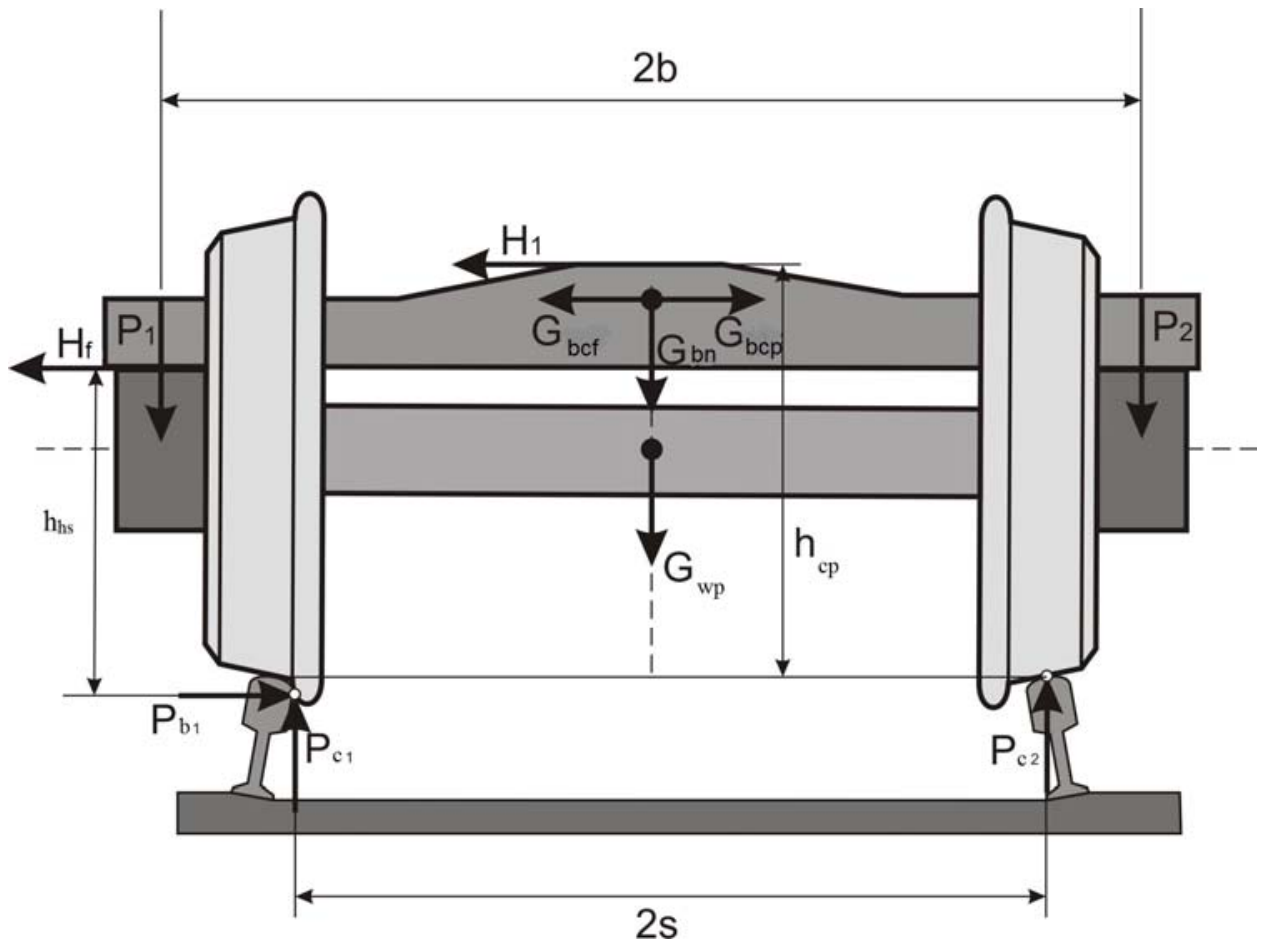

Having considered the balance conditions of a single wheel pair, we get $[6,22]$ :

$$
\left\{\begin{array}{l}
\sum Z=P_{1}+P_{2}+G_{w p}-N_{2}-P_{c a r}=0 \\
\sum M=N_{2} \cdot 2 S-G_{w p} \cdot S+P_{1} \cdot b_{1}- \\
-P_{2} \cdot b_{2}+H_{f} \cdot h_{h s}=0 \\
\sum Y=P_{f}-H_{f}-\mu \cdot N_{2}=0
\end{array}\right.
$$

Where $h_{\mathrm{hs}}$ - height from the rail level to the top plane of the central spring set, $\mathrm{m}$; $G_{\mathrm{wp}}-$ weight of the wheel pair, $\mathrm{kN} ; H_{\mathrm{f}}-$ frame force acting on the

Fig. 5. Calculation diagram of forces acting on the bogie as a result of longitudinal compression 


$$
\begin{aligned}
& P_{b}=\mu \cdot\left(\frac{G_{0}}{8}+\frac{G_{b g}}{4}\right)+\frac{N}{8} \cdot\left[\begin{array}{l}
\left.\left(\psi_{1}-\psi_{2}\right) \cdot\left(2-\mu \cdot \frac{h_{a}}{S}\right)-\mu \cdot\left(\varphi_{1}+\varphi_{2}\right) \cdot \frac{L \cdot b}{\ell \cdot S}+\mu \cdot\left(\varphi_{1}-\varphi_{2}\right) \cdot \frac{b}{S}+\right] \\
+\left(\psi_{1}+\psi_{2}+2 \psi\right) \cdot \frac{L}{\ell} \cdot\left(2-\mu \cdot \frac{h_{h s}}{S}\right)
\end{array}\right], \\
& K_{\mathrm{yв}}^{\mathrm{I}}=\frac{\operatorname{tg} \beta-\mu}{1+\mu \cdot \operatorname{tg} \beta} \times \\
& \times \frac{P_{c a r}+N \cdot\left[\Delta \psi \cdot \frac{h_{a}}{S}-\frac{b}{S}\left[\left(\varphi_{1}+\varphi_{2}\right) \cdot \frac{L}{\ell}+\Delta \varphi\right]+\left(\psi_{1}+\psi_{2}+2 \psi\right) \cdot \frac{L \cdot h_{\mathrm{hs}}}{\ell \cdot S}\right]}{\mu \cdot P_{c a r}+N \cdot\left[\Delta \psi \cdot\left(2-\mu \cdot \frac{h_{a}}{S}\right)+\mu \cdot \frac{b}{S}\left[\left(\varphi_{1}+\varphi_{2}\right) \cdot \frac{L}{\ell}+\Delta \varphi\right]+\left(\psi_{1}+\psi_{2}+2 \psi\right) \cdot \frac{L}{\ell} \cdot\left(2-\mu \cdot \frac{h_{\mathrm{hs}}}{S}\right)\right]} .
\end{aligned}
$$

Where $P_{\text {car }}=G_{\mathrm{o}}+2 G_{b}-$ car weight, $\mathrm{kN} ; \quad$ forces in the curve, the vertical (21) and the lateral $\Delta \psi=\psi_{1}-\psi_{2}-$ difference between the swivel angles of couplings against the track axis in front of and behind the car, rad.

(22) reactions of the rail on the climbing wheel are added to the inertia forces caused by unbalanced acceleration:

If it is necessary to take into account inertia

$$
\begin{gathered}
K_{\text {ув }}^{\mathrm{I}}=\operatorname{tg} \beta-\mu / 1+\mu \cdot \operatorname{tg} \beta \cdot P_{\mathrm{B}}+P_{\text {ин }} \cdot \frac{h_{\text {山 }}}{S} / P_{\text {б }}+P_{\text {ин }} \cdot\left(2-\mu \cdot h_{\mathrm{L}} / S\right), \\
P_{i n}=\left(G_{\mathrm{o}}+2 \cdot G_{b g}\right) \cdot \frac{a_{u n}}{g}=P_{c a r} \cdot \frac{a_{u n}}{g} .
\end{gathered}
$$

Using analytical expressions for determining ences for the vertical (21) and the lateral (22) reacangles $(10,11,12)$, we write the obtained depend- tions of the rail on the climbing wheel as follows:

$$
\begin{array}{r}
P_{b}=P_{\text {car }}^{s t}+\frac{N^{2}}{C_{\mathrm{r}}} \cdot\left[\frac{\psi_{a}^{2} \cdot h_{h s}}{2 \delta_{0} \cdot S}+\frac{\psi_{c u r} \cdot L}{a \cdot \ell}\left(\frac{h_{a}}{S}+\frac{a}{\ell} \cdot \frac{h_{h s}}{S}\right)\right]+N \cdot\left[2 \psi_{c u r} \cdot \frac{h_{a}}{S}+\psi_{a} \cdot \frac{h_{h s}}{S}\right], \\
P_{b}=\mu \cdot P_{c a r}^{s t}+\frac{N^{2}}{C_{\mathrm{r}}} \cdot\left[\frac{\psi_{a}^{2}}{2 \delta_{0}} \cdot\left(2-\mu \cdot \frac{h_{h s}}{S}\right)+\frac{\psi_{\mathrm{cur}} \cdot L}{a \cdot \ell}\left(2 \cdot\left(1+\frac{a}{\ell}\right)-\mu \cdot\left(\frac{h_{a}}{S}+\frac{a}{\ell} \cdot \frac{h_{h s}}{S}\right)\right)\right]+ \\
+N \cdot\left[2 \psi_{c u r} \cdot\left(2-\mu \cdot \frac{h_{a}}{S}\right)+\psi_{a} \cdot\left(2-\mu \cdot \frac{h_{h s}}{S}\right)\right] .
\end{array}
$$

Where $P_{c a r}^{s t}$ - static weight of car in view of unloading by longitudinal force, $\mathrm{kN}$;

$$
P_{c a r}^{s t}=P_{\text {car }}-N \cdot \varphi_{\ni},
$$

$\psi_{a}$ - rotation angle, rad;

$$
\psi_{a}=\delta_{0} \cdot L / \ell^{2} \cdot(1+L / a),
$$

$\psi_{\text {cur }}$ - rotation angle from the curve, rad;

$$
\psi_{\text {cur }}=L_{c} / R \text {. }
$$

Substituting the expressions (26) and (27) into the formula (24) we can obtain the dependence similar to that described in [6], excluding (31) and taking into account the inertial forces in a curve (32). In addition, we recall dependence for determining the longitudinal forces lift resistance factor excluding (33) and taking into account the inertial forces in a curve (34) which has been studied in [11]. 


$$
\begin{aligned}
& K_{r e s}^{\mathrm{I}}=\frac{\operatorname{tg} \beta-\mu}{1+\mu \cdot \operatorname{tg} \beta} \cdot \frac{P_{c a r}^{s t}+\frac{N^{2}}{C_{h}} \cdot\left[\frac{\psi_{a}^{2} \cdot h_{h s}}{2 \delta_{0} \cdot S}+\frac{\psi_{c u r} \cdot L}{a \cdot \ell}\left(\frac{h_{a}}{S}+\frac{a}{\ell} \cdot \frac{h_{h s}}{S}\right)\right]+N \cdot\left[2 \psi_{c u r} \cdot \frac{h_{a}}{S}+\psi_{a} \cdot \frac{h_{h s}}{S}\right]}{\mu \cdot P_{c s r}^{s t}+\frac{N^{2}}{C_{h}} \cdot\left[\frac{\psi_{a}^{2}}{2 \delta_{0}} \cdot\left(2-\mu \cdot \frac{h_{h s}}{S}\right)+\frac{\psi_{c u r} \cdot L}{a \cdot \ell}\left(2 \cdot\left(1+\frac{a}{\ell}\right)-\mu \cdot\left(\frac{h_{a}}{S}+\frac{a}{\ell} \cdot \frac{h_{h s}}{S}\right)\right)\right]+}, \\
& +N \cdot\left[2 \psi_{c u r} \cdot\left(2-\mu \cdot \frac{h_{a}}{S}\right)+\psi_{a} \cdot\left(2-\mu \cdot \frac{h_{h s}}{S}\right)\right] \\
& K_{r e s}^{\mathrm{I}}=\frac{\operatorname{tg} \beta-\mu}{1+\mu \cdot \operatorname{tg} \beta} \cdot \frac{P_{c a r}^{s t}+\frac{N^{2}}{C_{h}} \cdot\left[\frac{\psi_{a}^{2} \cdot h_{h s}}{2 \delta_{0}}+\frac{\psi_{c u r} \cdot L}{a \cdot \ell}\left(\frac{h_{a}}{S}+\frac{a}{\ell} \cdot \frac{h_{h s}}{S}\right)\right]+N \cdot\left[2 \psi_{c u r} \cdot \frac{h_{a}}{S}+\psi_{a} \cdot \frac{h_{h s}}{S}\right]+P_{i n} \cdot \frac{h_{c}}{S}}{\mu \cdot P_{c a r}^{\mathrm{st}}+\frac{N^{2}}{C_{h}} \cdot\left[\frac{\psi_{a}^{2}}{2 \delta_{0}} \cdot\left(2-\mu \cdot \frac{h_{h s}}{S}\right)+\frac{\psi_{c u r} \cdot L}{a \cdot \ell}\left(2 \cdot\left(1+\frac{a}{\ell}\right)-\mu \cdot\left(\frac{h_{a}}{S}+\frac{a}{\ell} \cdot \frac{h_{h s}}{S}\right)\right)\right]+}, \\
& +N \cdot\left[2 \psi_{c u r} \cdot\left(2-\mu \cdot \frac{h_{a}}{S}\right)+\psi_{a} \cdot\left(2-\mu \cdot \frac{h_{h s}}{S}\right)\right]+P_{i n} \cdot\left(2-\mu \cdot \frac{h_{c}}{S}\right) \\
& K_{r e s}^{\mathrm{I}, \mathrm{II}}=\frac{\operatorname{tg} \beta-\mu}{1+\mu \cdot \operatorname{tg} \beta} \cdot \frac{P_{\mathrm{T}}+\gamma N \cdot\left[\frac{\delta_{0} \cdot L}{\ell^{2}} \cdot\left(1+\frac{L}{a}\right) \cdot \frac{h_{c p}}{h_{c}} \pm \alpha \cdot \frac{L_{\mathrm{c}}}{R}\right] \cdot \frac{h_{c}}{S}}{\mu \cdot P_{\mathrm{T}}+2 \gamma N \cdot\left\{\frac{\delta_{0} \cdot L}{\ell^{2}} \cdot\left(1+\frac{L}{a}\right) \cdot\left(1-\mu \cdot \frac{h_{c p}}{2 S}\right) \pm \alpha \cdot \frac{L_{\mathrm{c}}}{R} \cdot\left(1-\mu \cdot \frac{h_{c}}{2 S}\right)\right\}}, \\
& K_{r e s}^{\mathrm{I}, \mathrm{II}}=\frac{\operatorname{tg} \beta-\mu}{1+\mu \cdot \operatorname{tg} \beta} \times \\
& \times \frac{P_{b g}+\gamma N \cdot\left[\frac{\delta_{0} \cdot L}{\ell^{2}} \cdot\left(1+\frac{L}{a}\right) \cdot \frac{h_{c p}}{h_{c p l}} \pm \alpha \cdot \frac{L_{\mathrm{c}}}{R}\right] \cdot \frac{h_{c p l}}{S} \pm \frac{1}{2} P_{i n} \cdot \frac{h_{c}}{S}}{\mu \cdot P_{\mathrm{T}}+2 \gamma N \cdot\left\{\frac{\delta_{0} \cdot L}{\ell^{2}} \cdot\left(1+\frac{L}{a}\right) \cdot\left(1-\mu \cdot \frac{h_{c}}{2 S}\right) \pm \alpha \cdot \frac{L_{\mathrm{c}}}{R} \cdot\left(1-\mu \cdot \frac{h_{c p l}}{2 S}\right) \pm P_{i n} \cdot\left(1-\mu \cdot \frac{h_{c}}{2 S}\right)\right\}} .
\end{aligned}
$$

Where $P_{\text {car }}-$ car weight, $\mathrm{kN} ; P_{\text {in }}-$ car inertial force, $\mathrm{kN} ; P_{b}-$ vertical load by bogie, which takes into account off-loading under the longitudinal force, $\mathrm{kN} ; N$ - longitudinal force on automatic coupling during the car compression, $\mathrm{kN} ; 2 L_{\mathrm{c}}-$ coupled length, $\mathrm{m} ; 2 L$ - car length over head stock, $\mathrm{m} ; 2 \ell$ - truck-centre spacing, $\mathrm{m} ; h_{\mathrm{cp}}-$ height of the centre plate working plane above the rail top, $\mathrm{m}$; $h_{h s}$ - height of the spring set top above the rail top, $\mathrm{m} ; h_{c p l-}$ height of the coupling axis above the rail top, $\mathrm{m} ; h_{\mathrm{c}}$ - height of the car gravity centre above the rail top, m. $2 b$ - distance between the points of application of the vertical forces acting on the journal box of the wheel pair on the climbing and non-climbing wheel respectively, $\mathrm{kN} ; 2 S-$ distance between the taping lines, $\mathrm{m} ; R$ - curve radius, $\mathrm{m} ; 2 \delta_{0}-$ total cross-run play of the car body frame relative to the track axis in the run section, $\mathrm{m} ; a$ - coupler casting length (from the axis of coupling to the end of the shank), $\mathrm{m} ; \mu$ - coefficient of flange friction against the rail top fillet; $\beta-$ angle formed by the straight part of the wheel flange profile contour to the track plane; $a_{\text {un }}-$ unbalanced acceleration, $\mathrm{m} / \mathrm{s}^{2} ; \alpha$ and $\gamma-$ coefficients taking into account the effect of longitudinal buckling forces, leading to a relative imbalance of cars and the coupling axes in the plan.

\section{Findings}

To assess the impact of the longitudinal forces value on the lift resistance factor Fig. 6 presents the calculation results for the empty gondola car motion, model No. 12-532, on $250 \mathrm{~m}$ radius curve with $150 \mathrm{~mm}$ rise and cross starting of car underframe relating to the track axis in $50 \mathrm{~mm}$ guiding section [12]. The calculations were made in such 
a curve excluding the inertial forces from outstanding acceleration and taking into account the unbalanced acceleration with the permissible speed of $65 \mathrm{~km} / \mathrm{h}[14,17]$.

Fig. 6 shows the calculation results for lift resistance factor of the empty car depending on the value of longitudinal forces caused by the neighbouring cars with the difference in coupling heights of $100 \mathrm{~mm}$. The horizontal lines show the allowable value of the lift resistance factor (1.2 [12]) and the value of this factor (1.0), which provides the necessary condition for instability.

The diagrams in Fig. 6 show that the car speed has some significant impact on the lift resistance factor value only at small values of the longitudinal forces, in case of which the lift is impossible. Therefore, as noted previously [3] and as follows from Fig. 6, the impact of the car speed on the longitudinal force lift resistance factor can be neglected.

Fig. 7 shows the dependence of the lift resistance factor obtained using 2 different design diagrams. The dotted line corresponds to the design diagram, which takes into account the loss of stability of the train, as the hinge-rod system [6]. The solid line - to calculation diagram, shown in Fig. 3.

This figure proves that, according to the results obtained from the formula (33), the lift resistance is not provided at the force $605 \mathrm{kN}$ and by the formula (31) - even at the force $530 \mathrm{kN}$.

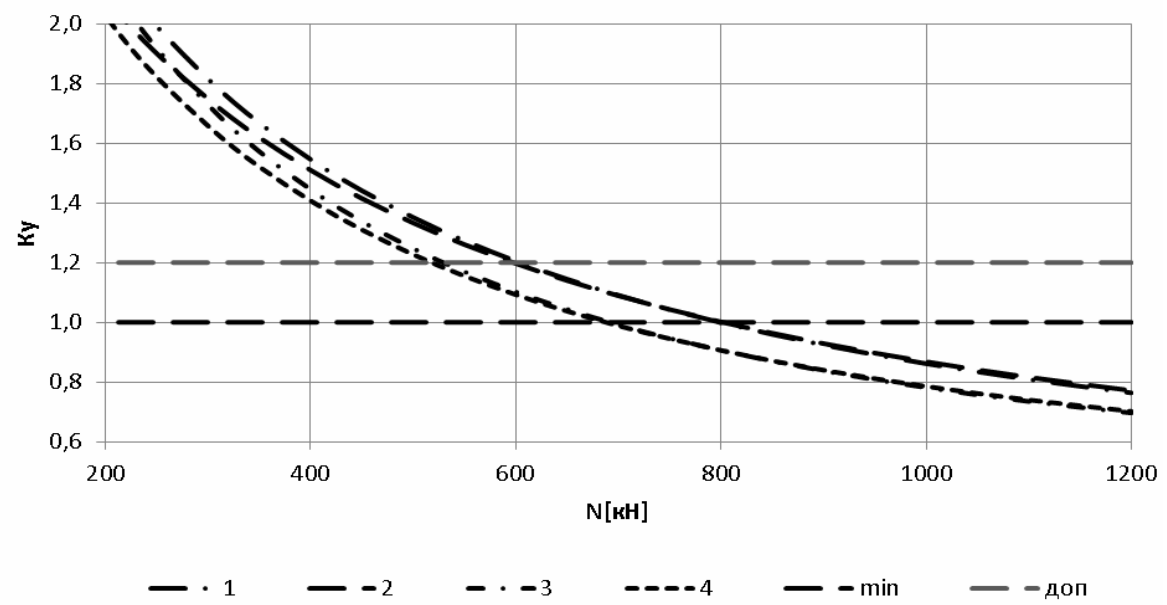

Fig. 6. Dependence diagram of lift resistance factor from longitudinal force:

1 - (33) without inertia force; 2 - (34) taking into account the inertia force by unbalanced acceleration;

3 - (31) without inertia force; 4 - (32) taking into account the inertia force by unbalanced acceleration

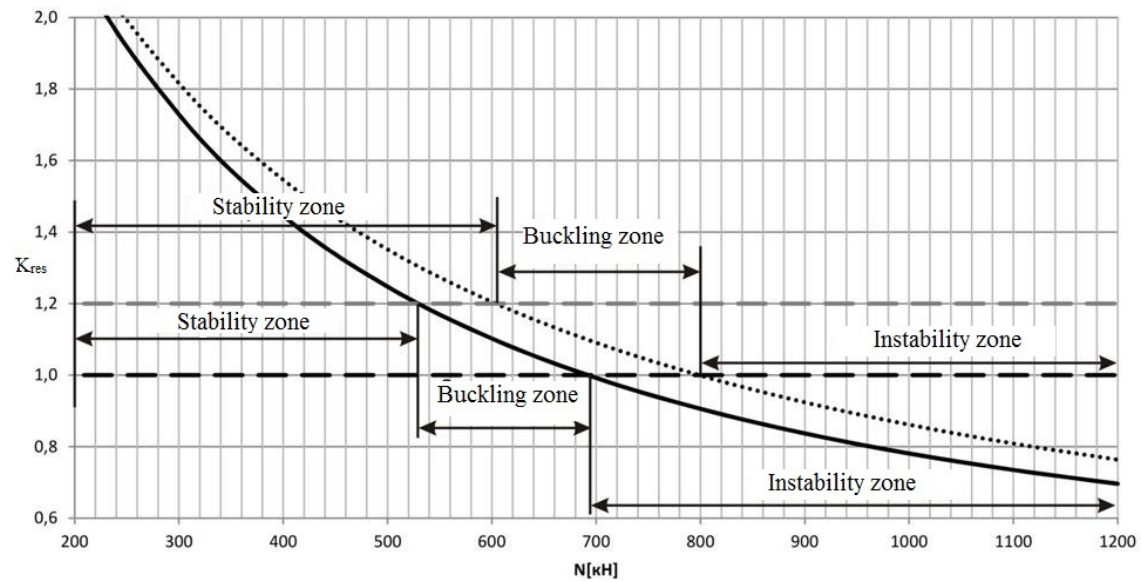

Fig. 7. Dependence diagram of lift resistance factor for different design schemes: solid line - (31), dotted line - (33) 
A necessary condition for the loss of stability is fulfilled, in the first case, when the value of the longitudinal force is $800 \mathrm{kN}$, in the second case $695 \mathrm{kN}$. Thus the results obtained by the formula (31) impose more stringent requirements to ensure the car lift resistance.

As it is known, the lowest values of the lift resistance factor are peculiar to the cars with small coupled length, truck-centre spacing and unladen weight. In future, the comparative analysis is made only for this category of freight cars $[4,5]$. The calculations were performed according to the dependencies (31) and (33) - excluding the inertial forces by unbalanced acceleration, and according to the dependencies (32) and (34) - taking into account the inertial forces by unbalanced acceleration when driving with permitted speed [17]. The results are summarized in Table $1-5$.

Table 1

The lift resistance factors for gondolas

\begin{tabular}{c|l|l|c}
\hline Formula No & \multicolumn{3}{|c}{ Covered car types } \\
\hline & $12-1505$ & $12-5326$ & $12-2122-01$ \\
$\begin{array}{c}\text { Standards } \\
{[10]}\end{array}$ & 1.367 & 1.399 & 1.360 \\
$\begin{array}{c}\text { Formula } \\
\text { (31) }\end{array}$ & 1.223 & 1.264 & 1.223
\end{tabular}

Table 2

The lift resistance factors for tank cars

\begin{tabular}{c|c|c|c}
\hline Formula No & \multicolumn{3}{|c}{ Tank-car types } \\
& $15-145$ & $15-869$ & $15-1548$ \\
$\begin{array}{c}\text { Standards } \\
{[10]}\end{array}$ & 1.597 & 1.647 & 1.423 \\
Formula (31) & 1.459 & 1.524 & 1.277
\end{tabular}

Table 3

The lift resistance factors for covered cars

\begin{tabular}{c|c|c|c}
\hline \multirow{2}{*}{ Formula No } & \multicolumn{3}{|c}{ Covered car types } \\
& $11-\mathrm{N} 002$ & $11-066$ & $10-475$ \\
\cline { 1 - 1 } $\begin{array}{c}\text { Standards } \\
{[10]}\end{array}$ & 1.315 & 1,492 & 1.642 \\
Formula (31) & 1.17 & 1.357 & 1.513
\end{tabular}

Table 4

The lift resistance factors for hopper cars

\begin{tabular}{c|c|c|c} 
Formula No & \multicolumn{3}{|c}{ Hopper car types } \\
\cline { 2 - 4 } & $11-715$ & $19-1217$ & $20-4078$ \\
Standards & 1.349 & 1.564 & 1.455 \\
{$[10]$} & & & \\
Formula (31) & 1.198 & 1.289 & 1.305
\end{tabular}

Table 5

The lift resistance factors for platforms

\begin{tabular}{|c|c|c|c|}
\hline \multirow[t]{2}{*}{ Formula No } & \multicolumn{3}{|c|}{ Platform types } \\
\hline & $\begin{array}{c}13- \\
1796\end{array}$ & $13-1798$ & $13-3103-01$ \\
\hline $\begin{array}{c}\text { Standards } \\
{[10]}\end{array}$ & 1.472 & 1.410 & 1.415 \\
\hline Formula (31) & 1.342 & 1.279 & 1.273 \\
\hline
\end{tabular}

The results of calculations in Tables 1-5 show that for all the above cars the values of the lift resistance factor obtained by the proposed formula (31) are smaller than the standards [12]. And for some cars the value $K_{\text {res }}$ is lower than the permissible value.

It follows that, even in the absence of «lift» according to the classical train stability theory, as the hinge-rod system, the presence of the longitudinal compressive forces may become a factor provoking cars derailment. Thus the main reason of wheel climbing on rails is the combination of processes of dynamic interaction between the hunting vehicle and the track with simultaneous action of longitudinal compressive forces, and not the destabilization of train as a hinged-rod system.

\section{Originality and practical value}

This study provides the technique of determining the lift resistance factor by longitudinal forces, which is somewhat different from the above mentioned one [3,6], as well as evaluates impact of rolling stock speed on this factor. The developed proposals for the refinement of existing methods for determining the resistance factor of the car lift by longitudinal force will increase the stability margin.

The research results have found their scientific use in a number of publications in the special and 
scientific journals, presentations at scientific meetings.

\section{Conclusions}

As a result of analytical research there are obtained the dependencies of longitudinal forced lift resistance factor in the train with and without consideration of the speed of its movement. It is shown that as the value of this factor gets closer to the buckling area the influence of speed decreases.

From these studies one can conclude that because of cars hunting their lift is possible even when the train as hinge-rod system does not lose stability.

Thus, the calculation results allow an objective assessment of the effect of the longitudinal force and the freight car speed on the lift resistance factor value.

\section{LIST OF REFERENCE LINKS:}

1. Аналіз стану безпеки руху поїздів у локомотивному господарстві залізниць України за 2010 рік // Локомотив-информ. - 2010. - № 5. C. $14-18$.

2. Вершинский, С. В. Динамика вагонов / С. В. Вершинский, В. И. Данилов, И. И. Челноков. - Москва : Транспорт, 1991. - 360 с.

3. Вершинский, С. В. Динамика, прочность и устойчивость вагонов в тяжеловесных и скоростных поездах / С. В. Вершинский // Сб. тр. / ВНИИЖТ. - Москва : Транспорт, 1970. - Вып. 425. $-208 \mathrm{c}$.

4. Грузовые вагоны колеи 1520 мм железных дорог СССР : альбом. - Москва : Транспорт. 1982. - $111 \mathrm{c}$.

5. Грузовые вагоны колеи 1520 мм железных дорог СССР : альбом-справочник / М-во путей сообщ. СССР, Гл. упр. вагон. хоз-ва. - Москва : Транспорт. - 1989. - 175 с.

6. Лазарян, В. А. Движение легковесных вагонов в составах тяжеловесных поездов / В. А. Лазарян, Е. П. Блохин, Е. Л. Стамблер / Тр. ДИИТа. - Москва : Транспорт, 1968. - Вып. 76 : Вопросы динамики подвижного состава и применения математических машин. - С. 34-46.

7. Лазарян, В. А. Динамика вагонов / В. А. Лазарян. - Москва : Транспорт, 1964. - 256 с.

8. Лазарян, В. А. Динамика транспортных средств / В. А. Лазарян. - Київ : Наукова думка, 1985. $-528 \mathrm{c}$.

9. Мямлин, С. В. Прогресс транспорта - залог развития национальной экономики / С. В. Мям- лин // Наука та прогрес трансп. Вісн. Дніпропетр. нац. ун-ту залізн. трансп. - 2013. - № 1 (43). - C. 7-12. doi: 10.15802/stp2013/9786.

10. Навчальні тренажери машиністів локомотивів / А. С. Акулов, К. І. Железнов, О. М. Заболотний [та ін.] // Проблеми та перспективи розвитку залізн. трансп. : тези 74 Міжнар. науковопракт. конф. (15.05-16.05.2014) / Мін-во інфраструктуры України, Дніпропетр. нац. ун-т залізн. трансп. ім. акад. В. Лазаряна. Дніпропетровськ, 2014. - С. 102-103.

11. Некоторые аспекты определения устойчивости порожних вагонов от выжимания их продольными силами в грузовых поездах / А. А. Швец, К. И. Железнов, А. С. Акулов [и др.] // Наука та прогрес трансп. Вісн. Дніпропетр. нац. ун-ту залізн. трансп. - 2015. - № 4 (58). - С. 175-189. doi: $10.15802 / \operatorname{stp} 2015 / 49281$.

12. Нормы для расчета и проектирования новых и модернизируемых вагонов железных дорог МПС колеи 1520 мм (несамоходных). - Москва : ВНИИВ : ВНИИЖТ, 1983. - 260 с.

13. О движении легковесных вагонов в составах тяжеловесных поездов : отчет о НИР : 80 / Днепропетр. ин-т инж. ж.-д. трансп. ; рук. Лазарян В. А. / Днепропетровск, 1966. - 38 с. Исполн.: Блохин Е. П., Стамблер Е. Л. - Библиогр.: с. 38. - Инв. № 80.

14. Определение допускаемых скоростей движения грузовых вагонов по ж.-д. путям колеи 1520 мм / В. Д. Данович, В. В. Рыбкин, С. В. Мямлин [и др.] // Вісн. Дніпропет. нац. ун-ту залізн. трансп. ім. акад. В. Лазаряна. Дніпропетровськ, 2003. - Вип. 2. - С. 77-86.

15. Пат. 87837 Україна. МПК $\mathrm{G} \quad 09$ В $9 / 04$ (20.06.01/). Тренажер для навчання машиніста магістрального локомотива / Железнов К. І., Акулов А. С., Євдомаха Г. В., Заболотний О. М., Чабанюк Є. В., Швець А. О. (Україна) ; заявник та патентовласник Дніпропетр. нац. ун-т залізн. трансп. ім. акад. В. Лазаряна. - № u 201309075 ; заявл. 19.07.2013 ; опубл. 25.02.14. Бюл. № 4. - 2 c.

16. Посмітюха, А. А. Аналіз стану безпеки руху поїздів у локомотивному господарстві залізниць України за 2008 рік / А. А. Посмітюха // Локомотив - информ. - 2009. - № 3/4. - С. 27-30.

17. Правила визначення підвищення зовнішньої рейки і встановлення допустимих швидкостей в кривих ділянках колії : ЦП 02336. - Київ : Укрзалізниця, 2013. - 44 с.

18. Продольная и поперечная динамика 2-осных автосцепных вагонов в тяжеловесных поездах и при повышенных скоростях : отчет о НИР / Всесоюз. науч.-исслед. ин-т ж.-д. трансп., 
Днепропетр. ин-т инженеров трансп. ; рук. Вершинский С. В. - Москва, 1954. - 312 с. - Исполн.: Лазарян В. А., Львов А. А., Блохин Е. П. - № И - $05-54$ р. 2. - Инв. № 2.

19. Продольная и поперечная динамика 2-осных вагонов в тяжеловесных поездах и при повышенных скоростях : отчет о НИР / Всесоюз. науч.-исслед. ин-т ж.-д. трансп., Днепропетр. инт инженеров трансп. ; рук. Вершинский С. В. Москва, 1953. - 351 с. - Исполн.: Лазарян В. А., Львов А. А., Конашенко С. И., Коротенко М. Л. № И $-05-54$ р. 1 . - Инв. № 1 .

20. Пустовгар, В. О. Аналіз стану безпеки руху поїздів у локомотивному господарстві залізниць України за 2009 рік / В. О. Пустовгар // Локомотив-информ. - 2010. - № 3. - С. 14-17.

21. Свідоцтво про реєстрацію авторського права на твір № 54184 Україна. Комп’ютерна програма «Обучение вождению поездов машинистов магистральных локомотивов» / Железнов К. І., Акулов А. С., Свдомаха Г. В., Заболотний О. М., Чабанюк С. В., Швець А. О. (Україна) ; заявник та патентовласник Дніпропетр. нац. ун-т залізн. трансп. ім. акад. В. Лазаряна. - заявл. 20.03.2014.

22. Шадур, Л. А. Вагоны. Конструкция, теория и расчет / Л. А. Шадур. - Москва : Транспорт, 1980. $-440 \mathrm{c}$.

23. Anyakwo, A. A New Method for Modelling and Simulation of the Dynamic Behaviour of the Wheel-rail Contact / A. Anyakwo, C. Pislaru, A. Ball // Intern. J. of Automation and Computing. - 2012. - Vol. 9. - Iss. 3. - P. 237-247. doi: 10.1007/s11633-012-0640-6.

24. Kurhan, D. M. Features of perception of loading elements of the railway track at high speeds of the movement / D. M. Kurhan // Наука та прогр. трансп. Вісн. Дніпропетр. нац. ун-ту залізн. трансп. - 2015. - № 2 (56). - С. 136-145. doi: $10.15802 /$ stp2015/42172.

25. Marquis, B. Application of Nadal limit in the prediction of wheel climb derailment (JRC201156064) / B. Marquis, R. Greif // Proc. of the ASME/ASCE/IEEE. 2011 Joint Rail Conf. (16.03.-18.03.2011). - Pueblo, Colorado, USA, 2011. - P. 1-8. doi: 10.1115/jrc2011-56064.

\section{А. О. ШВЕЦЬ ${ }^{1 *}$, К. І. ЖЕЛСЗНОВ ${ }^{2 *}$, А. С. АКУЛОВ ${ }^{3 *}$, О. М. ЗАБОЛОТНИЙ ${ }^{4 *}$, Є. В. ЧАБАНЮК ${ }^{5 *}$}

\footnotetext{
${ }^{1 *}$ СКТБ МСУБ, Дніпропетровський національний університет залізничного транспорту імені академіка В. Лазаряна, вул. Лазаряна, 2, Дніпропетровськ, Україна, 49010, тел. +38 (050) 21414 19, ел. пошта angela_shvets@ua.fm, ORCID 0000-0002-8469-3902

${ }^{2 *}$ СКТБ МСУБ, Дніпропетровський національний університет залізничного транспорту імені академіка В. Лазаряна, вул. Лазаряна, 2, Дніпропетровськ, Україна, 49010, тел. +38 (095) 54538 87, ел. пошта constantinz@i.ua, ORCID 0000-0003-3648-1769

${ }^{3 *}$ СКТБ МСУБ, Дніпропетровський національний університет залізничного транспорту імені академіка В. Лазаряна, вул. Лазаряна, 2, Дніпропетровськ, Україна, 49010, тел. +38 (067) 178 16 90, ел. пошта asakulov@gmail.com, ORCID 0000-0002-6123-5431

${ }^{4 *}$ СКТБ МСУБ, Дніпропетровський національний університет залізничного транспорту імені академіка В. Лазаряна, вул. Лазаряна, 2, Дніпропетровськ, Україна, 49010, тел. +38 (067) 28213 41, ел. пошта zabolotnyi@i.ua, ORCID 0000-0003-1651-7082

${ }^{5 *}$ СКТБ МСУБ, Дніпропетровський національний університет залізничного транспорту імені академіка В. Лазаряна, вул. Лазаряна, 2, Дніпропетровськ, Україна, 49010, тел. +38 (066) 63355 95, ел. пошта 457m@ukr.net, ORCID 0000-0001-5695-5955
}

\section{ДО ПИТАННЯ ВИЗНАЧЕННЯ КОЕФІЦІЕНТА ЗАПАСУ СТІЙКОСТІ ВІД ВИЧАВЛЮВАННЯ ЛЕГКОВАГОВИХ ВАГОНІВ}

Мета. Аналітичне дослідження зв'язку між поздовжньою силою, що діє на легковаговий вагон, бічними й вертикальними силами взаємодії в зоні контакту колеса та рейки з величиною коефіцієнта запасу стійкості від вичавлювання, передбачає отримання простих залежностей між ними. Методика. Дослідження проводилося методом математичного моделювання навантаженості вантажного вагона при русі з різними швидкостями по прямих та кривих ділянках шляху. Результати. Навіть за відсутності «вичавлювання» за класичною теорії стійкості поїзда, як шарнірно-стрижневої системи, наявність поздовжніх стискаючих сил може стати фактором, провокуючим схід вагонів. Основною причиною вповзання колеса на рейку 
є поєднання процесів динамічної взаємодії виляння екіпажа та колії з одночасною дією поздовжніх стискаючих сил, а не порушення стійкості поїзда як шарнірно-стрижневої системи. Для оцінки впливу величини поздовжніх сил на коефіцієнт запасу стійкості від вичавлювання наведені результати розрахунків руху порожнього піввагона моделі № 12-532 по кривій радіусом 250 м 3 піднесенням 150 мм й поперечним розгоном рами кузова вагона щодо осі колії в направляючому перетині в 50 мм. Розрахунки проводилися в такій кривій без урахування сил інерції від непогашеного прискорення та з урахуванням непогашеного прискорення при допустимій швидкості руху, рівній 65 км/год. Наукова новизна. У даному дослідженні наведено методику визначення коефіцієнта запасу стійкості від вичавлювання поздовжніми силами, яка дещо відрізняється від загальноприйнятої, а також оцінюється вплив на цей коефіцієнт швидкості руху рухомого складу. Практична значимість. Авторами уточнюється існуюча методика визначення коефіцієнта запасу стійкості від вичавлювання поздовжніми силами, а також оцінюється вплив на величину цього коефіцієнта швидкості руху рухомого складу. 3 проведених досліджень випливає, що через виляння вагонів їх вижимання можливо навіть тоді, коли поїзд, як шарнірно-стрижнева система, не втрачає стійкості. Розроблені пропозиції дозволяють знизити кількість сходів вагонів із рейок за рахунок обліку при розрахунках та проектуванні важливих параметрів й характеристик, що підвищують їх стійкість в рейковій колії (особливо при збільшенні швидкостей руху вантажних поїздів).

Ключові слова: безпека руху; норми для розрахунку; стійкість вагонів від вичавлювання; швидкість руху; коефіцієнт стійкості

\section{А. А. ШВЕЦ ${ }^{*}$, К. И. ЖЕЛЕЗНОВ ${ }^{2 *}$, А. С. АКУЛОВ ${ }^{3 *}$, А. Н. ЗАБОЛОТНЫЙ ${ }^{4 *}$, Е. В. ЧАБАНЮК ${ }^{5 *}$}

${ }^{1 *}$ СКТБ МСУБ, Днепропетровский национальный университет железнодорожного транспорта имени академика В. Лазаряна, ул. Лазаряна, 2, Днепропетровск, Украина, 49010, тел. +38 (050) 21414 19, эл. почта angela_shvets@ua.fm, ORCID 0000-0002-8469-3902

${ }^{2 *}$ СКТБ МСУБ, Днепропетровский национальный университет железнодорожного транспорта имени академика B. Лазаряна, ул. Лазаряна, 2, Днепропетровск, Украина, 49010, тел. +38 (095) 54538 87, эл. почта constantinz@i.ua, ORCID 0000-0003-3648-1769

$3^{*}$ СКТБ МСУБ, Днепропетровский национальный университет железнодорожного транспорта имени академика B. Лазаряна, ул. Лазаряна, 2, Днепропетровск, Украина, 49010, тел. +38 (067) 178 16 90, эл. почта asakulov@gmail.com, ORCID 0000-0002-6123-5431

${ }^{4 *}$ СКТБ МСУБ, Днепропетровский национальный университет железнодорожного транспорта имени академика В. Лазаряна, ул. Лазаряна, 2, Днепропетровск, Украина, 49010, тел. +38 (067) 28213 41, эл. почта zabolotnyi@i.ua, ORCID 0000-0003-1651-7082

$5^{5 *}$ СКТБ МСУБ, Днепропетровский национальный университет железнодорожного транспорта имени академика В. Лазаряна, ул. Лазаряна, 2, Днепропетровск, Украина, 49010, тел. +38 (066) 633 55 95, эл. почта 457m@ukr.net, ORCID 0000-0001-5695-5955

\section{К ВОПРОСУ ОПРЕДЕЛЕНИЯ КОЭФФИЦИЕНТА ЗАПАСА УСТОЙЧИВОСТИ ОТ ВЫЖИМАНИЯ ЛЕГКОВЕСНЫХ ВАГОНОВ}

Цель. Аналитическое исследование связи между продольной силой, действующей на легковесный вагон, боковыми и вертикальными силами взаимодействия в зоне контакта колеса и рельса с величиной коэффициента запаса устойчивости от выжимания, предполагает получение простых зависимостей между ними. Методика. Исследование проводилось методом математического моделирования нагруженности грузового вагона при движении с различными скоростями по прямым и кривым участкам пути. Результаты. Даже при отсутствии «выжимания» по классической теории устойчивости поезда, как шарнирностержневой системы, наличие продольных сжимающих сил может стать фактором, провоцирующим сход вагонов. Основной причиной всползания колеса на рельс является сочетание процессов динамического взаимодействия виляющего экипажа и пути с одновременным действием продольных сжимающих сил, а не нарушение устойчивости поезда как шарнирно-стержневой системы. Для оценки влияния величины продольных сил на коэффициент запаса устойчивости от выжимания приведены результаты расчетов движения порожнего полувагона модели № 12-532 по кривой радиусом 250 м с возвышением 150 мм и поперечным разбегом рамы кузова вагона относительно оси пути в направляющем сечении в 50 мм. Расчеты производились в такой кривой без учета сил инерции от непогашенного ускорения и с учетом 
непогашенного ускорения при допустимой скорости движения равной 65 км/ч. Научная новизна. В данном исследовании приведена методика определения коэффициента запаса устойчивости от выжимания продольными силами, несколько отличающаяся от общепринятой, а также оценивается влияние на этот коэффициент скорости движения подвижного состава. Практическая значимость. Авторами уточняется существующая методика определения коэффициента запаса устойчивости от выжимания продольными силами, а также оценивается влияние на величину этого коэффициента скорости движения подвижного состава. Из проведенных исследований следует, что из-за виляния вагонов их выжимание возможно даже тогда, когда поезд как шарнирно-стержневая система не теряет устойчивости. Разработанные предложения позволяют снизить количество сходов вагонов с рельсов за счет учета при расчетах и проектировании важных параметров и характеристик, повышающих их устойчивость в рельсовой колее (особенно при увеличении скоростей движения грузовых поездов).

Ключевые слова: безопасность движения; нормы для расчета; устойчивость вагонов от выжимания; скорость движения; коэффициент устойчивости

\section{REFERENCES}

1. Analiz stanu bezpeky rukhu poizdiv u lokomotyvnomu hospodarstvi zaliznyts Ukrainy za 2010 rik [Analysis of traffic safety in railway locomotive economy of Ukraine in 2010 year]. Lokomotyv-Inform - LocomotiveInform, 2010, no. 5, pp. 14-18.

2. Vershinskiy S.V., Danilov V.I., Chelnokov I.I. Dinamika vagonov [Dynamics of cars]. Moscow, Transport Publ., 1991. 360 p.

3. Vershinskiy S.V. Dinamika, prochnost i ustoychivost vagonov v tyazhelovesnykh i skorostnykh poyezdakh. [Dynamics, durability and the stability of cars in heavy and high-speed trains]. Sbornik trudov VNIIZhTa [Proc. Of All-Russian Research Railway Institute]. Moscow, Transport Publ., 1970, issue 425, 208 p.

4. Gruzovyye vagony kolei $1520 \mathrm{~mm}$ zheleznykh dorog SSSR: albom [Freight cars, a track of $1520 \mathrm{~mm}$ at railways of the USSR: The Album]. Moscow, Transport Publ., 1982. 111 p.

5. Gruzovyye vagony kolei $1520 \mathrm{~mm}$ zheleznykh dorog SSSR: albom-spravochnik [Freight cars $1520 \mathrm{~mm}$ track railways of the USSR: Album Directory]. Moscow, Transport Publ., 1989. 175 p.

6. Lazaryan V.A., Blokhin Ye.P., Stambler Ye.L. Dvizheniye legkovesnykh vagonov $\mathrm{v}$ sostavakh tyazhelovesnykh poyezdov. Voprosy dinamiki podvizhnogo sostava i primeneniya matematicheskikh mashin [Movement of lightweight cars in heavy trains. The dynamics of the rolling stock and the application of mathematical machines]. Trudy Dnepropetrovskogo instituta inzhenerov zheleznodorozhnogo transporta imeni akademika V. Lazariana [Studies of Dnepropetrovsk Institute of Railway Engineers named after Academician V. Lazaryan], 1966, issue 59, pp. 34-47.

7. Lazaryan V.A. Dinamica vagonov [Dynamics of cars]. Moscow, Transport Publ., 1964. 256 p.

8. Lazaryan V.A. Diynamica transportnykh sredstv [Dynamics of transportation facilities]. Kyiv, Naukova Dumka Publ., 1985. 528 p.

9. Myamlin S.V. Progress transporta - zalog razvitiya natsionalnoy ekonomiki [Transport progress as a pledge of national economy development]. Nauka ta prohres transportu. Visnyk Dnipropetrovskoho natsionalnoho universytetu zaliznychnoho transportu - Science and Transport Progress. Bulletin of Dnipropetrovsk National University of Railway Transport, 2013, issue 1 (43), pp. 7-12. doi: 10.15802/stp2013/9786.

10. Akulov A.S., Zhelieznov K.I., Zabolotnyi A.N., Povstenko J.L., Chabanyuk E.V., Shvets A.O. Navchalni trenazhery mashynistiv lokomotyviv [Training simulators of locomotive drivers]. Tezy 74 Mizhnarodnoi naukovo-praktychnoi konferentsii «Problemy ta perspektyvy rozvytku zaliznychnoho transportu» (15.0516.05.2014). [Proc. of the 74rd Int. Sci. and Practical Conf. «Problems and Prospects of Railway Transport»]. Dnipropetrovsk, 2014, pp. 102-103.

11. Shvets A.A., Zhelieznov K.I., Akulov A.S., Zabolotnyi A.N., Chabaniuk E.V. Nekotoryye aspekty opredeleniya ustoychivosti porozhnikh vagonov ot vyzhimaniya ikh prodolnymi silami $\mathrm{v}$ gruzovykh poyezdakh [Some aspects of the definition of empty cars stability from lift their longitudinal forces in the freight train]. Nauka ta prohres transportu. Visnyk Dnipropetrovskoho natsionalnoho universytetu zaliznychnoho transportu - Science and Transport Progress. Bulletin of Dnipropetrovsk National University of Railway Transport, 2015, issue № 4 (58), pp. 175-189. doi: 10.15802/stp2015/49281.

12. Normy dlya rascheta i proyektirovaniya novykh i moderniziruyemykh vagonov zheleznykh dorog MPS kolei $1520 \mathrm{~mm}$ (nesamokhodny $\mathrm{kh}$ ) [Standards for strength calculations and design of the mechanical part of the new 
and modernized railway cars MPS, track of 1520 mm (unpowered)]. Moscow, VNIIIV-VNIIZhT Publ., 1983. $260 \mathrm{p}$.

13. Lazaryan V.A., Blokhin Ye.P., Stambler Ye.L. O dvizhenii legkovesnykh vagonov v sostavakh tyazhelovesnykh poyezdov [About motion of lightweight cars in the heavy trains]. Dnipropetrovsk, 1966. $38 \mathrm{p}$.

14. Danovich V.D., Rybkin V.V., Myamlin S.V., Reidemeister A.G., Tryakin A.G., Halipova N.V. Opredeleniye dopuskayemykh skorostey dvizheniya gruzovykh vagonov po zheleznodorozhnym putyam kolei $1520 \mathrm{~mm}$ [Determining the permissible speed of freight cars on railroad tracks of $1520 \mathrm{~mm}$ ]. Visnyk Dnipropetrovskoho natsionalnoho universytetu zaliznychnoho transportu imeni akademika V. Lazariana [Bulletin of Dnipropetrovsk National University of Railway Transport named after Academician V. Lazaryan], 2003, issue 2, pp. 7786.

15. Zheleznov K.I., Akulov A.S., Yevdomakha H.V., Zabolotnyi O.M., Chabaniuk Ye.V., Shvets A.O. Trenazher dlia navchannia mashynista mahistralnoho lokomotyva [Simulator for driver training of the main locomotive]. Patent UA, no. u 2013 09075, 2014.

16. Posmitiukha A.A. Analiz stanu bezpeky rukhu poizdiv u lokomotyvnomu hospodarstvi zaliznyts Ukrainy za 2008 rik [Analysis of traffic safety in railway locomotive economy of Ukraine in 2008]. Lokomotiv-Inform Locomotive-Inform, 2009, no. 3/4, pp. 27-30.

17. Pravyla vyznachennia pidvyshchennia zovnishnoi reiky i vstanovlennia dopustymykh shvydkostei $v$ kryvykh diliankakh kolii. Ts $P 02336$ [The rules for superelevation determining of an outer rod and permissible speeds in curved sections of the track. TsP 02 336]. Kyiv, Ukrzaliznytsia Publ., 2013. 44 p.

18. Vershinskiy S.V., Lazaryan V.A., Lvov A.A., Blokhin Ye. P. Prodolnaya i poperechnaya dinamika 2-osnykh avtostsepnykh vagonov $v$ tyazhelovesnykh poyezdakh $i$ pri povyshennykh skorostyakh [Longitudinal and perpendicular dynamics of two axle automatic coupling cars in heavy trains and at the high speeds]. Moscow, VNIIZhT Publ., 1954. 312 p. No. I-05-54.

19. Vershinskiy S.V., Lazaryan V.A., Lvov A.A., Konashenko S.I., Korotenko M.L. Prodolnaya i poperechnaya dinamika 2-osnykh avtostsepnykh vagonov $v$ tyazhelovesnykh poyezdakh $i$ pri povyshennykh skorostyakh [Longitudinal and perpendicular dynamics of two axle automatic coupling cars in heavy trains and at the high speeds]. Moscow, VNIIZhT Publ., 1953. 351 p. No. I-05-54.

20. Pustovhar V.A. Analiz stanu bezpeky rukhu poizdiv u lokomotyvnomu hospodarstvi zaliznyts Ukrainy za 2009 rik [Analysis of traffic safety in railway locomotive economy of Ukraine in 2009]. Lokomotyv-infoUn Locomotive-Inform, 2010, no. 3, pp. 14-17.

21. Zheleznov K. I., Akulov A. S., Yevdomakha H. V., Zabolotnyi O. M., Chabaniuk Ye. V., Shvets A. O. Kompiuterna prohrama "Obucheniye vozhdeniyu poyezdov mashinistov magistralnykh lokomotivov» [Computer program «Learning to drive trains of drivers in mainline locomotives»]. Certificate UA, no. 54184, 2014.

22. Shadur L.A. Vagony. Konstruktsiya, teoriya i raschet [Cars. Design, theory and calculation]. Moscow, Transport Publ., 1980. 440 p.

23. Anyakwo A., Pislaru C., Ball A. New Method for Modelling and Simulation of the Dynamic Behaviour of the Wheel-rail Contact. Intern. Journal of Automation and Computing, 2012, vol. 9, issue 3, pp. 237-247. doi: 10.1007/s11633-012-0640-6.

24. Kurhan D.M. Features of perception of loading elements of the railway track at high speeds of the movement. Nauka ta prohres transportu. Visnyk Dnipropetrovskoho natsionalnoho universytetu zaliznychnoho transportu - Science and Transport Progress. Bulletin of Dnipropetrovsk National University of Railway Transport, 2015, issue 2 (56), pp. 136-145. doi: 10.15802/stp2015/42172.

25. Marquis B., Greif R. Application of Nadal limit in the prediction of wheel climb derailment (JRC2011-56064). Proc. of the ASME/ASCE/IEEE. 2011 Joint Rail Conf. (16.03.-18.03.2011). Pueblo, Colorado, USA, 2011. pp. 1-8. doi: 10.1115/jrc2011-56064.

Prof. S. V. Miamlyn, D. Sc. (Tech.), (Ukraine); Senior Associate M. M. Khachapurydze, PhD (Tech.), (Ukraine); Senior Associate M. O. Radchenko, PhD (Tech.), (Ukraine) recommended this article to be published

Received $\square$ Aug. 21, 2015

Accepted $\square$ Oct. 20, 2015 